\title{
First record of Banderomys leanzai Kramarz, 2005 (Rodentia, Caviomorpha) in Chubut Province, Patagonia (Argentina)
}

\author{
Felipe BUSKER ${ }^{1,5}$, María E. PÉREZ ${ }^{2,5}$, Javier M. KRAUSE ${ }^{3,5}$ \& María G. VUCETICH ${ }^{4,5}$
}

\begin{abstract}
${ }^{1}$ Instituto Patagónico de Geología y Paleontología, Centro Nacional Patagónico (IPGP, CCT CONICETCENPAT). Bvd. Brown 2915 (U9120ACD). Puerto Madryn, Chubut, Argentina. busker@cenpat-conicet.gob. ar. ${ }^{2}$ Museo Paleontológico Egidio Feruglio (MEF). Av. Fontana 140, Trelew (U9100GYO), Chubut, Argentina. Researcher Associate Field Museum of Natural History (FMNH), Chicago, IL, USA. mperez@mef.org.ar. ${ }^{3}$ Museo Paleontológico Egidio Feruglio, Av. Fontana 140, Trelew, (U9100GYO), Chubut, Argentina. Departamento de Geología, Universidad Nacional de la Patagonia San Juan Bosco, Comodoro Rivadavia, Chubut, Argentina. mkrause@mef.org.ar. ${ }^{4}$ División de Paleontología Vertebrados, Museo de La Plata, UNLP, Paseo del Bosque s/n, (B1900FWA) La Plata, Buenos Aires, Argentina. vucetich@fcnym.unlp.edu.ar. ${ }^{5}$ Consejo Nacional de Investigaciones Científicas y Técnicas (CONICET)
\end{abstract}

\begin{abstract}
Cephalomyidae was established in the XIX century, and was considered by different authors as a heterogeneous group of hypsodont South American hystricognath rodents. Other authors corroborated this family as a natural group among caviomorphs and recognized some taxa recorded from the Deseadan-Colhuehuapian South American Land Mammals Ages (SALMAs). Among them, Banderomys leanzai (the only species of this genus) was, until now, characteristic and exclusive of the locality of Cerro Bandera (early Miocene, Colhuehuapian?, Neuquén Province, Argentina). The aim of this work is to report the first record of $B$. leanzai outside the type locality; the new specimens come from the early Miocene of central Chubut Province (Patagonia, Argentina). This new finding extends the geographical distribution of the species and increases the dental morphology knowledge of B. leanzai.
\end{abstract}

Key words: Banderomys, Cephalomyidae, Hystricognathi, early Miocene, South America, Patagonia

Resumen: Primer registro de Banderomys leanzai Kramarz (Rodentia, Caviomorpha) en la provincia de Chubut, Patagonia (Argentina). Cephalomyidae fue establecida en el siglo XIX y considerada por diferentes autores como un grupo heterogéneo de roedores hystricognatos sudamericanos con dentición hipsodonte. Otros autores corroboraron a esta familia como un grupo natural dentro de los caviomorfos y reconocieron algunos taxones de las Edades Mamífero Deseadense-Colhuehuapense. Entre ellos, Banderomys leanzai (única especie del género) era, hasta el momento, característica y exclusiva de la localidad de Cerro Bandera (Mioceno temprano, Colhuehuapense?, provincia de Neuquén, Argentina). El objetivo de este trabajo es reportar el primer registro de B. leanzai fuera de la localidad tipo, los nuevos especímenes son del Mioceno temprano del centro de la provincia de Chubut (Patagonia, Argentina). Este nuevo hallazgo extiende la distribución geográfica de la especie e incrementa el conocimiento de la morfología dentaria de B. leanzai.

Palabras clave: Banderomys, Cephalomyidae, Hystricognathi, Mioceno temprano, América del Sur, Patagonia

\section{INTRODUCTION}

South American hystricognath rodents or Caviomorpha (e.g. viscachas, tuco-tucos, hutias, chinchillas, pacas, capybaras, porcupines) represent one of the most striking groups of the mammal assemblage of the continent (Mares \& Ojeda, 1982; Patton et al., 2015). The most ancient caviomorphs are known from the middle Eocene of Peru (Antoine et al., 2012), and for the late Oligocene (i.e. Deseadan SALMA) they were already highly diversified and widely distributed through South America (Vucetich et al., 2015a). During the late Oligocene, the four superfamilies currently recognized within caviomorph (Chinchilloidea, Cavioidea, Octodontoidea, and Erethizontoidea), were represented by many lineages that are now completely extinct (e.g. cephalomyids, "eocardiids", acaremyids). Among the latter, Cephalomyidae has been established by Ameghino (1897) on the basis of the Deseadan genus Cephalomys, which he considered as a 


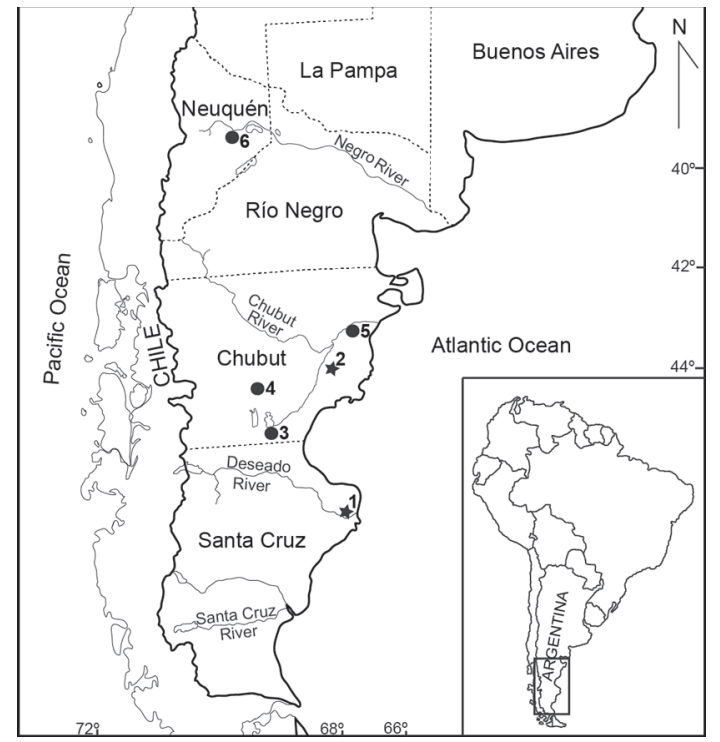

Fig. 1. Location map showing the Deseadan (stars) and Colhuehuapian (circles) Patagonian localities that share caviomorphs with Cerro Bandera locality: 1, La Flecha; 2, Cabeza Blanca; 3, Gran Barranca; 4, La Estrella; 5, Bryn Gwyn; 6, Cerro Bandera

group of caviomorph with generalized characters that originated the others South American hystricognath rodents. Other authors considered cephalomyids as a heterogeneous group that includes hypsodont forms (Cephalomys, Litodontomys Loomis, 1914; Cephalomyopsis Vucetich, 1985) with an enigmatic status, and uncertain phylogenetic relationships (Ameghino, 1897; Loomis, 1914; Simpson, 1945; Lavocat, 1976; Wood \& Patterson, 1959; Patterson \& Wood, 1982; Vucetich, 1985). Later, Kramarz described two new genera (Soriamys Kramarz, 2001 and Banderomys Kramarz, 2005) and performed a phylogenetic analysis that corroborated the monophyly of the family Cephalomyidae, recorded from the Deseadan-Colhuehuapian SALMAs (late Oligocene-early Miocene). During the last years only one new species (Cephalomys ceciae Vucetich et al., 2015b) from the Deseadan of Patagonia was described. Some doubtful records for the Santacrucian (early Miocene; Chinches Formation, San Juan, Argentina; López et al., 2011) and the Laventan SALMAs (middle Miocene; Quebrada Honda, Bolivia; Croft et al., 2011) were recognized but they need further revision. Cephalomyids have a wide geographical distribution with reports of records from the Bolivian localities of Salla (Lavocat, 1976) and Lacayani (Vucetich, 1989), and from the Argentinean provinces of Chubut, Santa Cruz, Neuquén, and Corrientes (Ameghino, 1897; Wood \& Patterson, 1959; Bond et al., 1998; Kramarz, 2001, 2005).

Banderomys leanzai Kramarz (2005), the only species of this genus, was originally described from Cerro Bandera (Neuquén province, Argentina; Fig. 1), initially considered early Miocene in age (Colhuehuapian? SALMA, but see Kramarz et al., 2011, 2013, 2015). B. lean$z a i$ is currently represented by scarce registers, including a poorly preserved mandible fragment, and some isolated teeth. Here, we report the first specimens of B. leanzai outside Cerro Bandera coming from a new locality in Chubut Province (Fig. 1). In addition, new dental material unknown for this species until now, provide a more complete knowledge of Banderomys enlarging the morphological information to future phylogenetic analysis.

\section{MATERIALS AND METHODS}

\section{Institutional abbreviations}

MOZ-PV, Museo Provincial de Ciencias Naturales "Dr. Prof. Juan A. Olsacher" Zapala, Neuquén, Argentina; MPEF-PV, Museo Paleontológico Egidio Feruglio - Paleontología de Vertebrados, Trelew, Chubut, Argentina; PVPH, Museo Municipal Carmen Funes, Plaza Huincul, Neuquén, Argentina.

\section{Dental nomenclature and abbreviations}

Dental nomenclature used here follows Arnal \& Vucetich (2015). Upper tooth abbreviations: $\mathrm{Al}$, anteroloph; Hf, hypoflexus; Ms, mesolophule; Msf, mesoflexus/mesofossette; Mt, metaflexus/ metafossette; Mel, metaloph; Pf, paraflexus/ parafossette; Prl, protoloph; Psl, posteroloph. Lower tooth abbreviations: af, anteroflexid/anterofossettid; hld, hypolophid; med I, metalophulid I; med II, metalophulid II; msf, mesoflexid/ mesofossettid; mt, metaflexid/metafossettid; psd, posterolophid.

\section{Material for comparison}

For taxonomic determination, we conducted an extensive bibliographic revision, and the new specimens were compared with materials housed at PVPH and MOZ-PV, listed in Supplementary Data. The measurements of the new specimens were obtained using a digital caliper with an accuracy of $0.01 \mathrm{~mm}$ (Table 1 ). 
Table 1. Dental measurements of Banderomys leanzai from La Estrella. Abbr.: AW, anterior maximum preserved width; $\mathbf{L}$, total preserved length; PW, posterior maximum preserved width. Measurements in $\mathrm{mm}$.

\begin{tabular}{lccc}
\hline \multicolumn{1}{c}{ Specimens } & L & AW & PW \\
\hline MPEF-PV 10996a M1or M2 & 3.14 & 3.11 & 2.89 \\
MPEF-PV 10996b M1 or M2 & 3.21 & 3.23 & 3.04 \\
MPEF-PV 10996c M1 or M2 & 3.09 & 3.24 & 3.05 \\
MPEF-PV 10996d m1 or m2 & 3.97 & 2.68 & 2.26 \\
MPEF-PV 10996e m3 & 4.59 & 3.99 & 3.52 \\
\hline
\end{tabular}

\section{GEOLOGICAL SETTING}

Fossil material described here proceed from "La Estrella" (S 44³5’36.60"; W 69 5’47.90”), named after its proximity (around $3 \mathrm{~km}$ in westeast direction) to the homonymous ranch, is located in the western part of the Meseta del Canquel, central Chubut Province, Argentina (Fig. 1) (see also Novo et al., 2017: figure 1). The rocks bearing the herein reported teeth belong to the Sarmiento Formation. The section characterizes by around $18 \mathrm{~m}$ of a monotonous succession of mostly massive, fine tuffs, ranging in color from pinkish grey, in the lower section, to greyish, in the top. The fossiliferous section overlies basalts cropping out in the middle section of Meseta del Canquel (e.g. Scarritt Pocket), indicating a postDeseadan age (Marshall et al., 1986; Vucetich et al., 2014), and underlies a basalt located toward the top of Meseta del Canquel, assigned by Marshall et al. (1986) to the lower Miocene. This stratigraphic position and similarities in lithological features recognized in La Estrella as well as in Gran Barranca (Spalletti \& Mazzoni, 1979) allow assigning the study section to the Colhué Huapí Member.

The fossil mammal assemblage at La Estrella, is represented by caviomorph rodents (Perimys, Banderomys, Eosteiromys), plathyrrhine primates (Mazzonicebus almendrae; Novo et al., 2017), xenarthrans (Dasypodinae, Glyptodontidae), Notongulata (Hegetotheriidae, Interatheriidae), and marsupials (Paucituberculata, Sparassodonta). Until now, Banderomys was exclusive from Cerro Bandera locality, considered early Miocene in age (Colhuehuapian?) by Kramarz (2005). However, Kramarz et al. (2011, 2013, 2015) questioned the age of Cerro Banderas due to the discovery of additional caviomorphs (e.g. Leucokephalos, Cephalomys) that are only present in the older Deseadan SALMA and suggested that “... the Cerro Bandera assemblage would represent a transitional association between the typical Deseadan and Colhuehuapian faunas, corresponding to a pre-Colhuehuapian age, not recorded elsewhere in South America" (Kramarz et al., 2011: 189). The presence of M. almendrae, Perimys and Eosteiromys at La Estrella and the absence of typical Deseadan taxa, suggests an age not older than the Colhuehuapian for this locality.

\section{SYSTEMATIC PALEONTOLOGY}

Order RODENTIA Bowdich, 1821 Suborder HYSTRICOGNATHI Tullberg, 1899 Family CEPHALOMYIDAE Ameghino, 1897

Genus Banderomys Kramarz, 2005

\section{Banderomys leanzai Kramarz, 2005}

Holotype. PVPH 367, left mandibular fragment with m1and $\mathrm{m} 2$ and the alveoli for the incisor and p4 (Kramarz, 2005: figs. 5A, 6).

Hypodigm. The new material described here MPEF-PV 10966a-e and the material listed in Kramarz 2005 (p. 251). MPEF-PV 10966a, left M1 or M2; MPEF-PV 10966b, right M1 or M2; MPEFPV 10966c, right M1 or M2; MPEF-PV 10966d, left $\mathrm{m} 1$ or $\mathrm{m} 2$; MPEF-PV 10966e, right m3.

\section{Geographic and stratigraphic provenance.} The new specimens come from La Estrella locality (Sarmiento Formation, Chubut Province, Argentina). All the material listed in Kramarz, 2005 (p. 252) come from Northwest of Sierra del Portezuelo Norte (Confluencia Department) and Cerro Bandera (Zapala Department), Cerro Bandera Formation, Neuquén Province, Argentina; pre-Colhuehuapian? - Colhuehuapian SALMA (early Miocene, Flynn \& Swisher, 1995).

Diagnosis (from Kramarz, 2005: 250-251). cephalomyid slightly larger than Cephalomys arcidens, with protohypsodont cheek teeth, lower crowned than in Cephalomys; unilateral hypsodonty in the uppers. Cement absent. Unworn or little worn upper molars with pentalophodont or tetralophodont occlusal pattern; the labial flexi are wide and transverse, and the hypoflexus extends less than half way across the occlusal surface. Worn upper molars with rounded labi- 
al fossettes; the mesofossette is the largest and most persistent, as in Cephalomys; hypoflexus extends only half way across the occlusal surface. Lower molars are tetralophodont during early and moderate stages of wear, lingual end of the metalophulid II connected with the posterolabial slope of the metaconid. The anterofossettid is the smallest and most ephemeral lingual flexid, and with wear the occlusal pattern turns trilophodont.

\section{Description and comparison}

The new specimens consist in isolated lower and upper teeth (Figs. 2, 3). The entire sample is assigned here to Banderomys leanzai, because the teeth share the combination of dental characters in the diagnosis for this species. Regarding general characteristics, the molariforms are protohypsodont, with crowns lower than Cephalomys, lack cement, and the enamel is continuous around the entire crown. The lower and upper dental series show an asymmetrical pattern, and with moderate wear, the occlusal surface becomes tetralophodont (Figs. 2A, B and see Kramarz, 2005). The upper molars have three roots, a large lingually and two smaller labially, like in Cephalomys and Soriamys. None of the lower molars preserved the roots in the new sample from Chubut.

Upper molars. Among the upper teeth in the new sample, there are three M1 or M2 (Figs. $2 \mathrm{~A}-\mathrm{C}$ and $3 \mathrm{~A}-\mathrm{C}$ ); all of them show unilateral hypsodonty. The MPEF-PV 10966a is a left M1 or M2 (Figs. 2A, 3A) with moderate stage of wear, the tooth appears to be tetralophodont but the posterior portion is broken and this cannot be corroborated. The hypoflexus is transversely short, V-shaped, and antero-posteriorly oriented, with the tip next to the paraflexus. The paraflexus and mesoflexus remain open, being the latter the deepest. These flexi are long and straight, wider labially, extending over the middle of the occlusal surface, and their lingual tips are slightly rounded. The only closed labial flexus is forming the metafossette, the anterior margin is relatively straight, and the lingual border is rounded. The postero-labial angle of the tooth is slightly broken and it is impossible to determine whether the posterofossette is present, although in this stage of wear, is usually present in the specimens from Cerro Bandera. The anterior margin of the anteroloph is straight and curved posteriorly at the lingual extreme. Thus, the protocone area is acute, while the hypocone area is more rounded and slightly more labial than the former. The anteroloph and protoloph are relatively straight; the mesolophule is curved postero-labially, and is probably joined to the metaloph.

The MPEF-PV 10966b is a right M1 or M2 (Figs. 2B, 3B) a little more worn than MPEF-PV 10966a; at this stage of wear it is clearly tetralophodont with the three labial fossettes completely close, and the posterofossette is absent. The hypoflexus is longer than in MPEF-PV 10966a, transversely extending almost up to the middle portion of the occlusal surface. It is V-shaped with the lingual tip acute, near the parafossette. The fossettes are transversely elongated, especially the mesofossette. The anteroloph is curved, protoloph and mesolophule are relatively straight, and the posteroloph present a widening at its labial end. In this stage of wear, the protocone and hypocone areas are more triangular in outline than in MPEF-PV 10966a, and they are mesio-distally aligned.

MPEF-PV 10966c is a right M1 or M2 (Figs. 2C, 3C), showing a more advanced stage of wear even than MPEF-PV 10966b; it is broken with the posterior and labial portions missing. The hypoflexus is longer than in the other upper teeth of the sample. It is quadrangular at the labial extreme. It is slightly oblique, and almost contacts the parafossette. Only the lingual portion of the parafossette and the mesofossette are preserved, and they are rounded. The protocone area is rounded.

Lower molars. The lower teeth are represented by a $\mathrm{m} 1$ or $\mathrm{m} 2$ and the first $\mathrm{m} 3$ reported for $B$. leanzai (Figs. 2D-E, 3D-E). MPEF-PV 10966d is a left $\mathrm{m} 1$ or $\mathrm{m} 2$ (Figs. 2D, 3D) and it is badly damaged, with the entire lingual and postero-labial portion lost. The hypoflexid is wide and V-shaped, and is very close to the metafossettid. The preserved anterior margin of the metalophulid I is straight, while the posterior wall of the tooth appears to be oblique, typical of $B$. leanzai lower teeth. There is only a small vestige of the anterofossettid, almost lost due to wear. The preserved labial portion of the mesofossettid and metafossettid are rounded. The protoconid and hypoconid area are acute and mesio-distally aligned.

The MPEF-PV 10966e is a right m3 with moderate wear (Figs. 2E, 3E). It is assigned to a $\mathrm{m} 3$ due to the short posterior lophid and lack of wear facet on the posterior wall. Metalophulid I and II are connected at the lingual extreme, defining a small and boomerang-shaped anterofossettid. This fossettid is the first one formed, and 

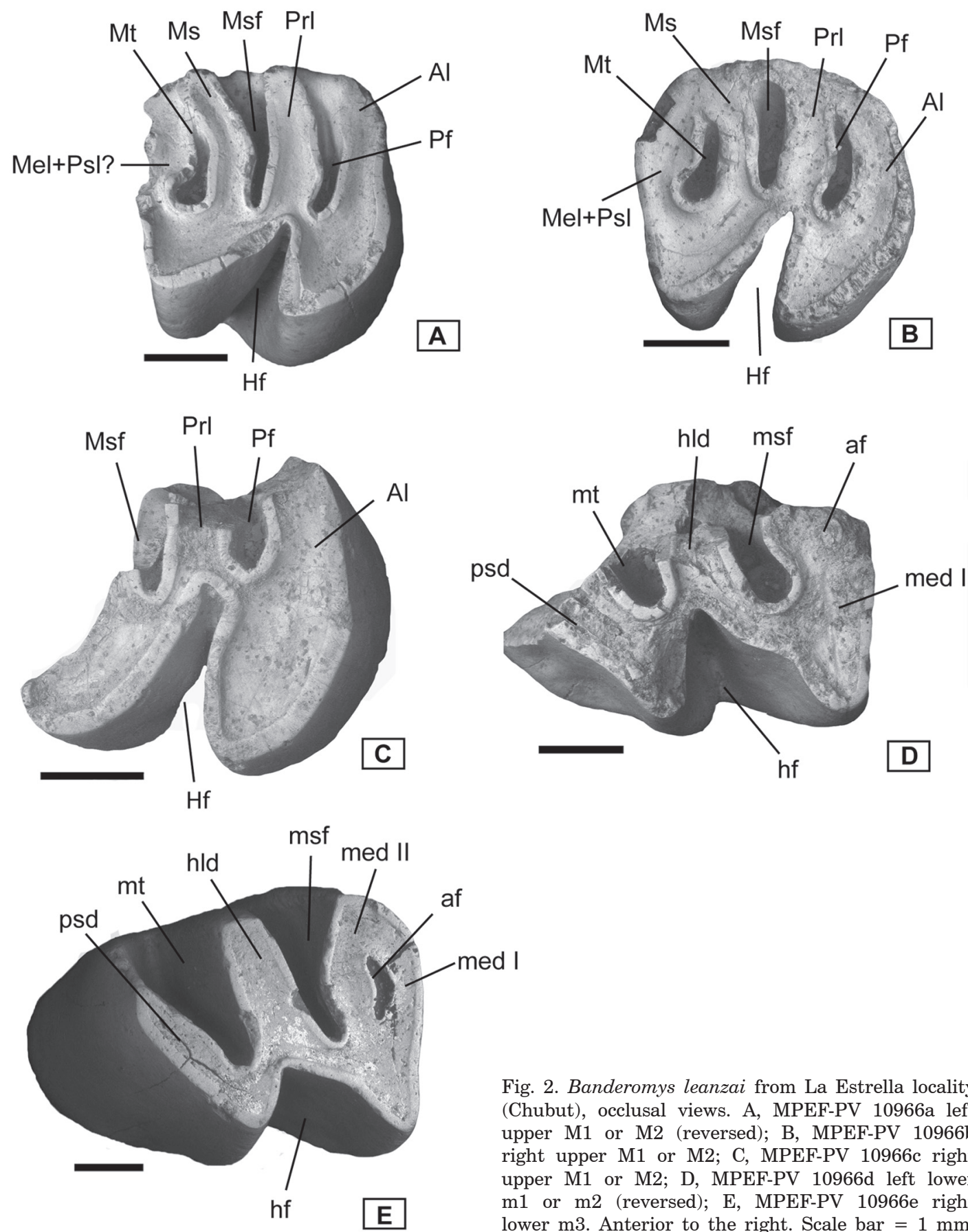

Fig. 2. Banderomys leanzai from La Estrella locality (Chubut), occlusal views. A, MPEF-PV 10966a left upper M1 or M2 (reversed); B, MPEF-PV 10966b right upper M1 or M2; C, MPEF-PV 10966c right upper M1 or M2; D, MPEF-PV 10966d left lower $\mathrm{m} 1$ or $\mathrm{m} 2$ (reversed); E, MPEF-PV 10966e right lower $\mathrm{m} 3$. Anterior to the right. Scale bar $=1 \mathrm{~mm}$.

it would be rapidly lost with more wear. The hypolophid is wide and straight, and is as long as the metalophulids. The posterolophid is the shortest lophid with an antero-posteriorly oblique orientation, so the trigonid is much longer than the talonid. The area of the protoconid is more la- bial than the hypoconid area. The mesoflexid is funnel shaped and large, extending beyond the middle of the occlusal surface. Its labial extreme is rounded and slightly curved anteriorly. The metaflexid also extends beyond the middle of the tooth, almost reaching the hypoflexid. It is 


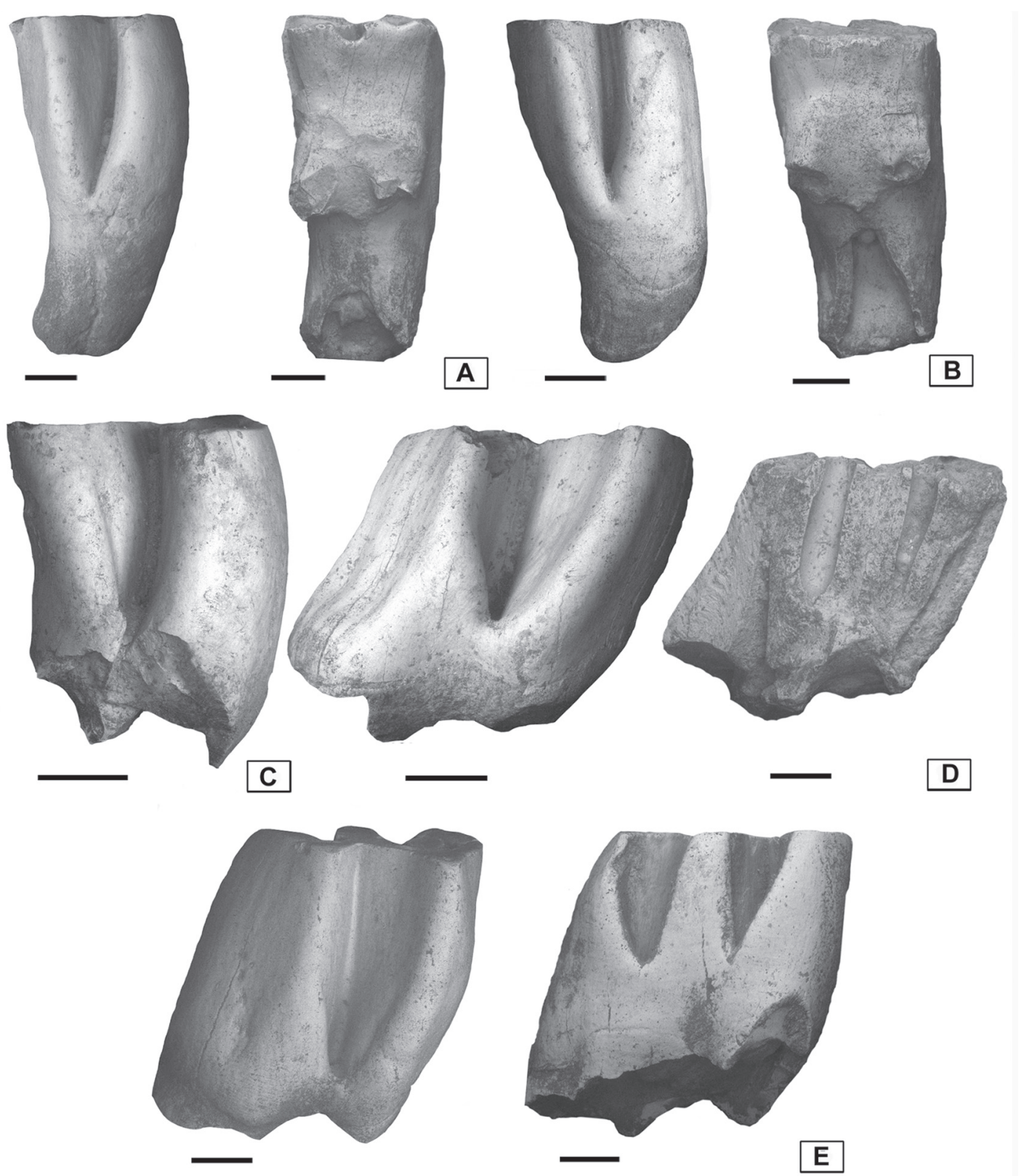

Fig. 3. Banderomys leanzai A, MPEF-PV 10966a lingual (reversed) and labial view; B, MPEF-PV 10966b lingual and labial (reversed) view; C, MPEF-PV 10966c lingual view; D, MPEF-PV 10966d labial (reversed) and lingual view; E, MPEF-PV 10966e labial and lingual (reversed) view. Anterior to the right. Scale bar $=1 \mathrm{~mm}$.

transversal, with a rounded labial extreme and triangular outline. The mesoflexid is the last flexid to become a fossettid, but it seems that this is slightly variable between the specimens from Cerro Bandera. The hypoflexid is short and wide, with a V-shape outline and antero-posteriorly oblique. It does not pass the middle of the tooth and is markedly shorter than the lingual flexid.

\section{DISCUSSION AND CONCLUSIONS}

The family Cephalomyidae is an enigmatic group of caviomorph rodents, from a taxonomic and phylogenetic point of view. They are recorded from Deseadan to Colhuehuapian SALMAs, in middle (Bolivia) and high latitudes (Patagonia, Argentina) of South America (Ameghino, 1897; 
Loomis, 1914; Wood \& Patterson, 1959; Lavocat, 1976; Patterson \& Wood, 1982; Vucetich, 1985, 1989; Kramarz, 2001, 2005). Frailey (1981) mentioned the presence of Cephalomys for the middle Miocene of Quebrada Honda (Bolivia), but we have not seen this material.

Thecephalomyids known from Colhuehuapian localities in Patagonia (Fig. 1) come from Bryn Gwyn (Soriamys gaimanensis, Cephalomyopsis hypselodontus), Gan Gan (S. ganganensis), and Gran Barranca (cephalomyid indet.) in Chubut Province, and Cerro Bandera (Banderomys leanzai) in Neuquén Province (Vucetich, 1985; Kramarz, 2001, 2005; Vucetich et al., 2010).

Here we report the first specimens assigned to Banderomys leanzai outside of its type locality in a Colhuehuapian locality (La Estrella, Fig. 1; Novo et al., 2017) of Chubut Province. The age of La Estrella locality is supported by the sedimentological data (see Geological Setting above) and mammal assemblage, especially by the presence of Mazzonicebus almendrae, Perimys and Eosteiromys which are not found in older SALMAs. This new record enlarges the geographical distribution of $B$. leanzai for the Colhuehuapian SALMA.

Most genera of caviomorph rodents found in Cerro Bandera are present in other pre-Deseadan to "Colloncuran" localities of Argentina, Bolivia, and Chile.

Eosteiromys? (see Vucetich et al., 2010), Caviocricetus, Galileomys, and Eoviscaccia from Cerro Bandera, are also recorded in Gran Barranca and Bryn Gwyn localities in Chubut Province (Colhuehuapian SALMA; Vucetich et al., 2010). Eosteiromys is also found in the Pinturas Formation (Santa Cruz Province, Argentina; Kramarz, 2004). Eoviscaccia is also recorded in some Deseadan localities such as Cabeza Blanca (Chubut Province, Argentina) and Lacayani (Bolivia) (Vucetich, 1989), and in the Tinguirirican locality of Chile (Bertrand et al., 2012), whereas Galileomys is found in Cañadon del Tordillo ("Colloncuran" SALMA, Neuquén Province; Vucetich \& Kramarz, 2003) and Pinturas Formation (Kramarz, 2004). Leucokephalos (exclusive of the Deseadan age; Vucetich et al., 2015b) come from Cabeza Blanca. Cephalomys is found in several Deseadan localities of Argentina and Bolivia, the best knowns are La Flecha (Santa Cruz Province, Argentina; Loomis, 1914) and Cabeza Blanca (Wood \& Patterson, 1959). Banderomys is now recorded in La Estrella locality and in this context, Doryperimys and Garridomys (Kramarz et al.,
$2013,2015)$ are the only exclusive caviomorph rodents of Cerro Bandera Formation. If an earlier age is corroborated for Cerro Bandera, the biochron of this species would encompass a preColhuehuapian to Colhuehuapian age.

Cephalomyids are poorly known, excepting Cephalomys; and thus, more collection efforts are needed in order to find more and more complete material that allow to shed light to this intriguing caviomorph family.

\section{ACKNOWLEDGEMENTS}

We want to thank to Eduardo Ruigomez and Juliana Sterli (MPEF), Rodolfo Coria (PVPH) and Belen Boilini (MOZ) for the access to the material under study. To Pablo Puerta for his technical support during the fieldwork. To ALUAR (Aluminios Argentinos, Puerto Madryn) and M. Luquet for providing access to the Scanning Electron Microscope to take the pictures. To Mariana Viglino for useful corrections in the English version of this manuscript. This study was partially funded by ANPCyT-PICT 20121483 (M.G. Vucetich) and ANPCyT-PICT 20120326 (E. Bellosi). The Museo Paleontológico Egidio Feruglio provided logistical support for the fieldwork.

\section{REFERENCES}

Ameghino, F. 1897. Mamíferos cretáceos de la Argentina. Segunda contribución al conocimiento de la fauna mastozoológica de las capas con restos de Pyrotherium. Bol Inst Geográfico Argentino 18: 406-429, 431-521.

Antoine, P.O., L. Marivaux, D.A. Croft, G. Billet, M. Ganerød, C. Jaramillo, T. Martin, M.J. Orliac, J. Tejada, A.J. Altamirano, F. Duranthon, G. Fanjat, S. Rousse \& R.S. Gismondi. 2012. Middle Eocene rodents from Peruvian Amazonia reveal the pattern and timing of caviomorph origins and biogeography. Proc R Soc Lond B Biol Sci. 279 (1732): 1319-1326.

Arnal, M. \& M.G. Vucetich. 2015. Main radiation events in Pan-Octodontoidea (Rodentia, Caviomorpha). Zool. J. Linn. Soc 175 (3): 587-606.

Bond, M., G. López, M. Reguero, G.J. Scillato-Yané \& M.G. Vucetich. 1998. Los mamíferos de la Formación Fray Bentos (Edad mamífero deseadense, Oligoceno superior?) de las provincias de Corrientes y Entre Ríos, Argentina. Asociación Paleontológica Argentina, Publicación Especial 5, 41-50.

Bertrand, O.C., J.J. Flynn, D.A Croft \& A.R. Wyss. 2012. Two New Taxa (Caviomorpha, Rodentia) from the Early Oligocene Tinguiririca Fauna (Chile). $₫ \mathrm{Am}$. Mus. Novit 3750, 1-36. 
Bowdich, T.E. 1821. An analysis of the natural classifications of Mammalia for the use of students and travellers. J. Smith, París, Francia, 115 pp.

Croft, D.A., J.M.H. Chick \& F. Anaya. 2011. New Middle Miocene caviomorph rodents from Quebrada Honda, Bolivia. JJ. Mammal 18 (4): 245-268.

Flynn, J.J. \& C.C. Swisher. 1995. Cenozoic South American land mammal ages: correlation to global geochronologies. In W.A. Berggren, D.V. Kent \& J. Hardenbol (eds.), Geochronologies, Time Scales, and Global Stratigraphic Correlation, vol. 54. pp. 317-333 Society for Sedimentary Geology, Special Publication.

Frailey, C.D. 1981. Studies on the Cenozoic vertebrata of Bolivia and Peru. Unpublished PhD Thesis, University of Kansas: i-iii, 1-257.

Kramarz, A.G. 2001. Revision of the family Cephalomyidae (Rodentia, Caviomorpha) and new cephalomyids from the Early Miocene of Patagonia. Palaeovertebrata 30 (1-2): 51-88.

Kramarz, A.G. 2004. Octodontoids and erethizontoids (Rodentia, Hystricognathi) from the Pinturas Formation, Early - Middle Miocene of Patagonia, Argentina. Ameghiniana 41 (2): 1-19.

Kramarz, A.G. 2005. A primitive cephalomyid hystricognath rodent from the early Miocene of northern Patagonia, Argentina. Acta Palaeontol. Pol. 50 (2): 249-258.

Kramarz, A.G., M. Tejedor, A. Forasiepi \& A. Garrido. 2011. New early Miocene primate fossils from Northern Patagonia, Argentina. J. Hum. Evol 62 (2012): 186-189.

Kramarz A.G., M.G. Vucetich \& M. Arnal. 2013. A New Early Miocene Chinchilloid Hystricognath Rodent; an Approach to the Understanding of the Early Chinchillid Dental Evolution. J. Mammal. Evol. 20: 249-261.

Kramarz, A.G., M. Bond \& M. Arnal. 2015. Systematic description of three new mammals (Notoungulata and Rodentia) from the early Miocene Cerro Bandera Formation, northern Patagonia, Argentina. Ameghiniana 52 (6): 585-597.

Lavocat, R. 1976. Rongeurs caviomorphes del'Oligocene de Bolivie. II. Rongeurs du Bassin Deseadien de Salla-Luribay. Paleovertebrata 7, 15-90.

Loomis, F.B. 1914. The Deseado Formation of Patagonia. Amherst Rumford Press, Concord, New Hampshire, $232 \mathrm{pp}$.

López, G.M., M.G. Vucetich, A.A. Carlini, M. Bond, M.E. Pérez, M.R. Ciancio, D.J. Perez, M. Arnal \& I. Olivares. 2011. New Miocene mammal assemblages from Neogene Manantiales basin. In J. Salfity \& R. Marquillas (eds.), Cenozoic Geology of the Central Andes of Argentina, pp. 211-226, SCS Publisher.

Mares, M.A. \& R.A. Ojeda. 1982. Patterns of diversity and adaptation in South American Hystricognath rodents. In M.A. Mares \& H.H. Genoways (eds.), Mammalian Biology in South America, pp 393-432 (6). Special Publication Pymatuning Laboratory of Ecology, University of Pittsburg.

Marshall, L.G., R.L. Cifelli, R.E. Drake \& G.H. Curtis. 1986. Vertebrate paleontology, geology, and geo- chronology of the Tapera de López and Scarritt Pocket, Chubut Province, Argentina. EJ. Paleo 60: 920-951.

Novo, N, Tejedor, M., Pérez, M. E. \& Krause, M. 2017. New primate locality from the early Miocene of Patagonia, Argentina. Am. J. Phys. Anthropol. Doi: 10.1002/ajpa.23309

Patterson, B. \& A.E Wood. 1982. Rodents from the Deseadan Oligocene of Bolivia and the relationships of the Caviomorpha. Bull. Mus. Comp. Zool. 149, 370-543.

Patton, J.L., U.F.J. Pardiñas \& G. D’Elía (eds.). 2015. Mammals of South America. Volume 2 - Rodents. Chicago and London: The University of Chicago Press.

Simpson, G.G. 1945. The principles of classification and a classification of mammals. Bull. Am. Mus. Nat. Hist. 85: 1-350.

Spalletti, L.A., \& M.M. Mazzoni. 1979. Estratigrafía de la Formación Sarmiento en la barranca sur del lago Colhue Huapi, provincia del Chubut. Rev. Asoc. Geol. Argent. 34 (4): 271-281.

Tullberg, T. 1899. Ueber das system der Nagetiere: Eine phylogenetische studie. Nova Acta Regiae Societatis Scientiarum Upsaliensis 3: 1-514.

Vucetich, M.G. 1985. Cephalomyopsis hipselodontus gen. et sp. nov. (Rodentia, Caviomorpha, Cephalomyidae) de la Edad Colhuehuapense (Oligoceno tardío) de Chubut, Argentina. Ameghiniana 22 (3-4): 243-245.

Vucetich, M.G. 1989. Rodents (Mammalia) of the Lacayani fauna revisited (Deseadan, Bolivia). Comparison with new Chinchillidae and Cephalomyidae from Argentina. Bull. Mus. Hist. Nat. 11: 233-247.

Vucetich, M.G. \& A.G. Kramarz. 2003. New Miocene rodents from Patagonia (Argentina) and their bearing on the early radiation of the octodontoids (Hystricognathi). J. Vert. Paleontol 23 (2): 435444.

Vucetich, M.G., A.G. Kramarz \& A.M. Candela. 2010. Colhuehuapian rodents from Gran Barranca and other Patagonian localities: the state of the art. In R.H. Madden, A.A. Carlini, M.G. Vucetich \& R.F. Kay (eds.), The Paleontology of Gran Barranca Evolution and Environmental Change through the Middle Cenozoic of Patagonia pp. 206-219, Cambridge, UK: Cambridge University Press.

Vucetich, M.G., M.E. Pérez, M.R. Ciancio, A.A. Carlini, R.H. Madden \& M.J. Kohn. 2014. A new acaremyid rodent (Caviomorpha, Octodontoidea) from Scarritt Pocket, Deseadan (Late Oligocene) of Patagonia (Argentina). J. Vert. Paleontol 34 (3): 689-698.

Vucetich, M.G., M. Arnal, C.M. Deschamps, M.E. Peréz \& E.C. Vieytes. 2015a. A brief history of caviomorph rodents as told by the fossil record. In A.I. Vassallo \& D. Antenucci (eds.), Biology of Caviomorph Rodents: Diversity and Evolution pp. 11-62, SAREM Series A.

Vucetich, M.G., M.T. Dozo, M. Arnal \& M.E. Pérez. 2015b. New rodents (Mammalia) from the late Oligocene of Cabeza Blanca (Chubut) and the first 
rodent radiation in Patagonia. Hist. Biol. 27 (2): 236-257.

Wood, A.E. \& B. Patterson. 1959. The rodents of the
Deseadan Oligocene of Patagonia and the beginnings of South American rodent evolution. Bull. Mus. Comp. Zool. 120: 281-428.

Doi: 10.22179/REVMACN.19.533

Recibido: 31-VII-2017

Aceptado: 14-IX-2017 
